\title{
Bacillus chungangensis sp. nov., a halophilic species isolated from sea sand
}

\author{
Sung-Lim Cho, Min Young Jung, Mi-Hak Park and Wonyong Kim
}

Correspondence

Wonyong Kim

kimwy@cau.ac.kr
Department of Microbiology and Research Institute for Translational System Biomics, Chung-Ang University College of Medicine, 221 Heukseok-dong, Dongjak-gu, Seoul 156-756, Republic of Korea

The taxonomic position of a Gram-stain-positive, endospore-forming, halophilic strain, designated CAU $348^{\top}$, isolated from sea sand was investigated using a polyphasic approach. Colony morphology, biochemical tests and chemotaxonomic investigations revealed that strain CAU $348^{\top}$ had the characteristics of the genus Bacillus. Comparative 16S rRNA gene sequence analysis showed that the organism formed a hitherto unknown subline within the genus Bacillus.

Sequence divergence values of more than $4.3 \%$ from other described Bacillus species, together with phenotypic differences, showed that the unidentified bacterium represents a previously unrecognized member of this genus. The genotypic and phenotypic data indicated that strain CAU $348^{\top}$ represents a novel species of the genus Bacillus, for which the name Bacillus chungangensis sp. nov. is proposed. The type strain is $\mathrm{CAU}_{348^{\top}}\left(=\mathrm{KCTC} 13566^{\top}=\mathrm{CCUG}^{\top}\right.$ $\left.57835^{\top}\right)$.
Aerobic, endospore-forming, halophilic Gram-positive rods are taxonomically very diverse and have been isolated from different saline habitats such as salterns, estuarine water, salt lakes, salty foods, sea ice and deep-sea hydrothermal vents (Agnew et al., 1995; Arahal et al., 1999; Nielsen et al., 1994; Ventosa et al., 1989; Yoon et al., 2004). Recently, novel approaches in the study of bacterial systematics have aided the reclassification of many species assigned to the genus Bacillus (Ash et al., 1993; Heyndrickx et al., 1998; Shida et al., 1996; Wisotzkey et al., 1992). In particular, comparative 16S rRNA gene sequence analysis has shown that the genus Bacillus contains six phylogenetically distinct groups and that many alkaliphilic/ halophilic bacilli belong to rRNA Bacillus group 6 (Ash et al., 1991; Nielsen et al., 1994).

In the course of screening micro-organisms from marine habitats in Jeju island, an aerobic, Gram-stain-positive, halophilic bacterium, designated CAU $348^{\mathrm{T}}$, was isolated and characterized. The genotypic and phenotypic data obtained in this study suggest that the strain CAU $348^{\mathrm{T}}$ represents a novel species of the genus Bacillus.

The procedure for isolation of strain CAU $348^{\mathrm{T}}$ followed that of Gordon \& Mihm (1962) by using glucose-yeast extract agar (GYEA) $\left(1^{-1}: 10\right.$ g yeast extract, 10 g glucose, $15 \mathrm{~g}$ agar) supplemented with $50 \mathrm{mg}$ cycloheximide and $20 \mathrm{mg}$ nalidixic acid $1^{-1}$. A sand sample was diluted with

The GenBank/EMBL/DDBJ accession number for the 16S rRNA gene sequence of strain CAU $348^{\top}$ is FJ514932.

An electron micrograph showing a cell of strain $\mathrm{CAU} 348^{\top}$ is available as supplementary material with the online version of this paper. sterilized distilled water, spread onto the GYEA medium and incubated aerobically for 3 days at $30{ }^{\circ} \mathrm{C}$.

The pure culture of CAU $348^{\mathrm{T}}$ was preserved in $25 \%(\mathrm{v} / \mathrm{v})$ glycerol at $-70{ }^{\circ} \mathrm{C}$. Cell morphology was examined by light microscopy (model DM 1000; Leica). Flagellum type was examined using cells from exponentially growing cultures. The cells were negatively stained with $1 \%(\mathrm{w} / \mathrm{v})$ phosphotungstic acid and, after air drying, the grids were examined using a TEM (model CM-20; Philips). Catalase activity was determined by bubble production in a $3 \%(\mathrm{v} / \mathrm{v})$ hydrogen peroxide solution. Oxidase activity was tested by means of the oxidation of $1 \%(\mathrm{w} / \mathrm{v})$ tetramethyl-p-phenylenediamine (Merck). Hydrolysis of casein, starch and urea was determined on GYEA according to the methods described by Cowan \& Steel (1965), Lányí (1987) and Smibert \& Krieg (1994). Acid production from carbohydrates was tested as described by Leifson (1963) and using the API 50CH system (bioMérieux), according to the manufacturer's instructions, with incubation for up to 3 days at $30{ }^{\circ} \mathrm{C}$. Growth at various $\mathrm{NaCl}$ concentrations $(0-15 \%)$ at $30{ }^{\circ} \mathrm{C}$ was investigated on GYEA or glucose-yeast extract broth (GYEB). Growth at various temperatures and $\mathrm{pH}$ values was investigated on GYEA between 4 and $45{ }^{\circ} \mathrm{C}$.

Cellular fatty acid methyl esters were extracted after incubation for 3 days on tryptic soy agar (TSA; Difco) by acid methanolysis (Minnikin et al., 1980) and analysed using a Hewlett Packard series II gas chromatograph model 5890 A equipped with a $5 \%$ phenyl methyl silicon-fused silica capillary column (HP 19091B-102). Preparation of cell walls and analysis of peptidoglycan structures were carried out using the methods described by Schleifer 
(1985), with the modification that TLC on cellulose sheets was performed instead of paper chromatography. Polar lipids were extracted from freeze-dried cell material (100 mg) by using a two-stage method and separated by two-dimensional silica-gel TLC as described by Tindall $(1990 \mathrm{a}, \mathrm{b})$. Menaquinones were analysed as described by Komagata \& Suzuki (1987) using reversed-phase HPLC.

Genomic DNA of strain CAU $348^{\mathrm{T}}$ was isolated and purified by the method of Marmur (1961). The G+C content of the genomic DNA was determined using SYBR Green I with a real-time thermocycler (model 7300; Applied Biosystems) and the fluorimetric method of Gonzalez \& Saiz-Jimenez (2002). PCR amplification and sequencing of the $16 \mathrm{~S}$ rRNA gene were carried out following established procedures (Nam et al., 2004). The PCR amplification products were sequenced directly using a BigDye Terminator cycle sequencing kit and an automatic DNA sequencer (model 3730; Applied Biosystems). Multiple alignments with sequences from a broad selection of Bacillus species and calculations of sequence similarity were carried out by using CLUSTAL x (Thompson et al., 1997) and the EzTaxon server (Chun et al., 2007). A phylogenetic tree was constructed using the neighbourjoining algorithm (Saitou \& Nei, 1987) from the PHYLIP suite of programs (Felsenstein, 1989). Evolutionary distance matrices were generated by the neighbour-joining method described by Jukes \& Cantor (1969) and tree topology was evaluated by bootstrap resampling (Felsenstein, 1985) with 1000 replicates of the neighbourjoining dataset with the SEQBOOT and CONSENSE programs from the PHYLIP package.

Colonies of strain CAU $348^{\mathrm{T}}$ were $0.2-0.3 \mathrm{~mm}$ wide and $0.8-1.0 \mathrm{~mm}$ long. Cells of the isolate were short rods, approximately $0.8 \times 2.5 \mu \mathrm{m}$ after 3 days of cultivation at $30{ }^{\circ} \mathrm{C}$ on GYEA, and were strictly aerobic. Strain CAU $348^{\mathrm{T}}$ was motile by means of peritrichous flagella (Supplementary Fig. S1, available in IJSEM Online). Strain CAU $348^{\mathrm{T}}$ grew with $0-15 \%$ (w/v) $\mathrm{NaCl}$ [optimum $5 \%(\mathrm{w} / \mathrm{v}) \mathrm{NaCl}$, at $4-45{ }^{\circ} \mathrm{C}$ (optimum $30{ }^{\circ} \mathrm{C}$ ) and at pH 4.5-9.0 (optimum pH 7.0).

Strain CAU $348^{\mathrm{T}}$ contained meso-diaminopimelic acid as the diagnostic diamino acid in the cell-wall peptidoglycan. The predominant isoprenoid quinone in strain CAU $348^{\mathrm{T}}$ was unsaturated menaquinone with seven isoprene units (MK-7). The major polar lipids of strain $348^{\mathrm{T}}$ were phosphatidylglycerol, diphosphatidylglycerol and phosphatidylethanolamine. TLC analysis of whole-cell hydrolysates revealed mainly ribose and glucose. The cellular fatty acid profile of the strain grown on TSBA was characterized by saturated branched fatty acids such as iso- $\mathrm{C}_{13: 0}(2.5 \%)$, iso- $\mathrm{C}_{14: 0} \quad(1.1 \%)$, iso- $\mathrm{C}_{15: 0} \quad(68.8 \%)$, anteiso- $\mathrm{C}_{15: 0}$ $(17.4 \%)$, iso- $\mathrm{C}_{16: 0}(1.3 \%), \mathrm{C}_{16: 0}(2.3 \%)$, iso- $\mathrm{C}_{17: 0}$ $(2.1 \%)$, and anteiso- $\mathrm{C}_{17: 0}(3.2 \%)$. Cells were positive for catalase, oxidase and urease but negative for starch hydrolysis. API 50CHB test strips provided adequate phenotypic data to describe the new isolate, and a detailed description of the key phenotypic characteristics of the isolate is given in Table 1 and the species description. Acid was produced from fructose, glucose, rhamnose, ribose, salicin, sucrose, D-tagatose, arbutin and aesculin, but not from glycerol, D-arabinose, galactose, mannitol, mannose, raffinose or D-xylose.

The DNA G+C content of strain CAU $348^{\mathrm{T}}$ was $35.0 \mathrm{~mol} \%$. The nearly complete $16 \mathrm{~S}$ rRNA gene sequence of strain CAU $348^{\mathrm{T}}$ (1468 bp) was determined and compared with the corresponding sequences of other bacterial strains in the GenBank database. A phylogenetic tree based on 16S rRNA gene sequence data from strain CAU $348^{\mathrm{T}}$ and corresponding sequences from the type strains of recognized Bacillus species as well as Aneurinibacillus migulanus DSM $2895^{\mathrm{T}}$ was constructed according to the neighbour-joining algorithm (Fig. 1). The genus Bacillus embraces a very diverse range of organisms. It is recognized, however, that the genus is not monophyletic and comprises several distinct $16 \mathrm{~S}$ rRNA gene sequence lineages. The tree topology, supported by high bootstrap values, clearly separated strain CAU $348^{\mathrm{T}}$ within the genus Bacillus lineage from Aneurinibacillus migulanus DSM $2895^{\mathrm{T}}$, which formed an outlying single-membered cluster. It is evident from our $16 \mathrm{~S}$ rRNA gene sequence

Table 1. Differential phenotypic properties between strain CAU $348^{\top}$ and the type strains of closely related Bacillus species

Strains: 1, Bacillus chungangensis sp. nov. CAU $348^{\mathrm{T}} ; 2, \quad B$. carboniphilus Kasumi $6^{\mathrm{T}}$ (data from Fujita et al., 1996); 3, B. sporothermodurans $\mathrm{M} 215^{\mathrm{T}}$ (Pettersson et al., 1996); 4, B. shackletonii SSI024 ${ }^{\mathrm{T}}$ (Logan et al., 2004); 5, B. acidicola 105-2 ${ }^{\mathrm{T}}$ (Albert et al., 2005). +, Positive; $\mathrm{w}$, weakly positive; - , negative.

\begin{tabular}{|lccccc|}
\hline Characteristic & $\mathbf{1}$ & $\mathbf{2}$ & $\mathbf{3}$ & $\mathbf{4}$ & $\mathbf{5}$ \\
\hline Hydrolysis of: & & & & & \\
Casein & + & + & - & w & - \\
Starch & - & + & - & - & - \\
Acid from: & & & & & \\
D-Arabinose & - & - & - & + & - \\
Fructose & + & - & w & + & - \\
Glucose & + & - & - & + & - \\
Mannose & - & - & - & + & - \\
Rhamnose & + & - & - & - & - \\
Ribose & + & - & w & - & - \\
Salicin & + & - & - & + & - \\
Sucrose & + & - & - & - & - \\
D-Tagatose & + & W & - & + & - \\
D-Xylose & - & + & - & - & - \\
Mannitol & - & - & - & w & - \\
Arbutin & + & - & - & + & - \\
Aesculin & + & + & - & + & - \\
Cell-wall & Rib, Glc & Rib, Xyl & Rib, Glc & Rib Rib, Glc, Gal \\
sugar(s) & & & & & \\
\hline
\end{tabular}

${ }^{\star}$ Gal, Galactose; Glc, glucose; Rib, ribose; Xyl, xylose. 


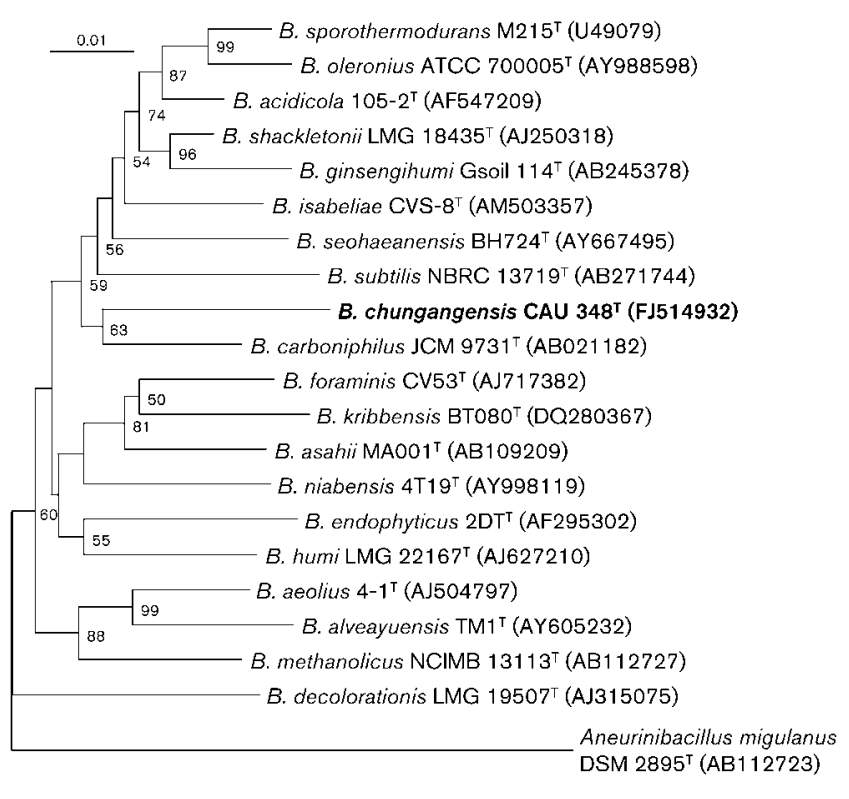

Fig. 1. Neighbour-joining phylogenetic tree based on nearly complete 16S rRNA gene sequences showing the relationships between strain CAU $348^{\top}$ and members of the genus Bacillus. Bootstrap values ( $>50 \%$ ) based on 1000 resamplings are shown at branch nodes. Bar, 0.01 substitutions per nucleotide position.

study that strain CAU $348^{\mathrm{T}}$ forms a distinct subclade with Bacillus carboniphilus JCM $9731^{\mathrm{T}}$, B. sporothermodurans $\mathrm{M} 215^{\mathrm{T}}$, B. shackletonii $\mathrm{LMG} 18435^{\mathrm{T}}$, B. acidicola $105-2^{\mathrm{T}}, B$. seohaeanensis $\mathrm{BH} 724^{\mathrm{T}}$, B. oleronius ATCC $700005^{\mathrm{T}}, B$. isabeliae CVS- $8^{\mathrm{T}}$ and B. ginsengihumi Gsoil $114^{\mathrm{T}}$. The pairwise similarity between strain CAU $348^{\mathrm{T}}$ and $B$. carboniphilus JCM $9731^{\mathrm{T}}$ was $95.6 \%$ and similarities with other described members of this genus were lower, indicating clearly that strain CAU $348^{\mathrm{T}}$ represents a novel species belonging to the genus Bacillus (Stackebrandt \& Goebel, 1994).

These phenotypic and chemotaxonomic data, together with the $16 \mathrm{~S}$ rRNA gene sequence analysis, provide sufficient evidence to support the proposal that strain CAU $348^{\mathrm{T}}$, isolated from sea sand, represents a hitherto unrecognized species within the genus Bacillus. The name Bacillus chungangensis sp. nov. is proposed for this novel taxon.

\section{Description of Bacillus chungangensis sp. nov.}

Bacillus chungangensis (chung.an.gen'sis. N.L. masc. adj. chungangensis named after Chung-Ang University, where taxonomic studies on the type strain were performed).

Cells are strictly aerobic, Gram-stain-positive, motile, spore-forming short rods, $0.8 \times 2.5 \mu \mathrm{m}$. Colonies are creamy, smooth and circular on GYEA media agar after $72 \mathrm{~h}$ incubation at $30^{\circ} \mathrm{C}$. Growth occurs at $4-45{ }^{\circ} \mathrm{C}$ (optimum $30{ }^{\circ} \mathrm{C}$ ), $\mathrm{pH} 4.5-9.0$ (optimum pH 7.0) and 0-15\% (w/v) $\mathrm{NaCl}$ (optimum 5\%). Catalase- and oxidasepositive. Acid production occurs from ribose, glucose, fructose, rhamnose, arbutin, aesculin, salicin, sucrose and D-tagatose but not from glycerol, D-arabinose, D-xylose, galactose, mannose, mannitol or raffinose. The cell wall contains meso-diaminopimelic acid. The major isoprenoid quinone is MK-7. The major polar lipids are phosphatidylglycerol, diphosphatidylglycerol and phosphatidylethanolamine. Whole-cell hydrolysates contain mainly ribose and glucose. The predominant cellular fatty acids $(>10 \%)$ are iso- $\mathrm{C}_{15: 0}$ and anteiso- $\mathrm{C}_{15: 0}$. The DNA G+C content of the type strain is about $35.0 \mathrm{~mol} \%$.

The type strain, CAU $348^{\mathrm{T}}$ (=KCTC $13566^{\mathrm{T}}=$ CCUG $57835^{\mathrm{T}}$ ), was isolated from sea sand from Jeju island, Republic of Korea.

\section{Acknowledgements}

This work was supported by the 21C Frontier Microbial Genomics and Application Center Program, Ministry of Education, Science and Technology (grant MG 11-2008-03-002-00), Republic of Korea. We are grateful to Dr Nagamani Bora (Aston University, UK) for providing editorial assistance with the English text.

\section{References}

Agnew, M. D., Koval, S. F. \& Jarrell, K. F. (1995). Isolation and characterization of novel alkaliphiles from bauxite-processing waste and description of Bacillus vedderi sp. nov., a new obligate alkaliphile. Syst Appl Microbiol 18, 221-230.

Albert, R. A., Archambault, J., Rosselló-Mora, R., Tindall, B. J. \& Matheny, M. (2005). Bacillus acidicola sp. nov., a novel mesophilic, acidophilic species isolated from acidic Sphagnum peat bogs in Wisconsin. Int J Syst Evol Microbiol 55, 2125-2130.

Arahal, D. R., Marquez, M. C., Volcani, B. E., Schleifer, K.-H. \& Ventosa, A. (1999). Bacillus marismortui sp. nov., a new moderately halophilic species from the Dead Sea. Int J Syst Bacteriol 49, 521530.

Ash, C., Farrow, J. A. E., Wallbanks, S. \& Collins, M. D. (1991). Phylogenetic heterogeneity of the genus Bacillus as revealed by comparative analysis of small-subunit ribosomal RNA sequences. Lett Appl Microbiol 13, 202-206.

Ash, C., Priest, F. G. \& Collins, M. D. (1993). Molecular identification of rRNA group 3 bacilli (Ash, Farrow, Wallbanks and Collins) using a PCR probe test. Proposal for the creation of a new genus Paenibacillus. Antonie van Leeuwenhoek 64, 253-260.

Chun, J., Lee, J. H., Jung, Y., Kim, M., Kim, S., Kim, B. K. \& Lim, Y. W. (2007). EzTaxon: a web-based tool for the identification of prokaryotes based on $16 \mathrm{~S}$ ribosomal RNA gene sequences. Int J Syst Evol Microbiol 57, 2259-2261.

Cowan, S. T. \& Steel, K. J. (1965). Manual for the Identification of Medical Bacteria. London: Cambridge University Press.

Felsenstein, J. (1985). Confidence limits on phylogenies: an approach using the bootstrap. Evolution 39, 783-791.

Felsenstein, J. (1989). PHYLIP - phylogeny inference package (version 3.2). Cladistics 5, 164-166.

Fujita, T., Shida, O., Takagi, H., Kunugita, K., Pankrushina, A. N. \& Matsuhashi, M. (1996). Description of Bacillus carboniphilus sp. nov. Int J Syst Bacteriol 46, 116-118. 
Gonzalez, J. M. \& Saiz-Jimenez, C. (2002). A fluorimetric method for the estimation of $\mathrm{G}+\mathrm{C}$ mol\% content in microorganisms by thermal denaturation temperature. Environ Microbiol 4, 770-773.

Gordon, R. E. \& Mihm, J. M. (1962). Identification of Nocardia caviae (Erikson) nov. comb. Ann N Y Acad Sci 98, 628-636.

Heyndrickx, M., Lebbe, L., Kersters, K., De Vos, P., Forsyth, G. \& Logan, N. A. (1998). Virgibacillus: a new genus to accommodate Bacillus pantothenticus (Proom and Knight 1950). Emended description of Virgibacillus pantothenticus. Int J Syst Bacteriol 48, 99-106.

Jukes, T. H. \& Cantor, C. R. (1969). Evolution of protein molecules. In Mammalian Protein Metabolism, vol. 3, pp. 21-132. Edited by H. N. Munro. New York: Academic Press.

Komagata, K. \& Suzuki, K. (1987). Lipid and cell-wall analysis in bacterial systematics. Methods Microbiol 19, 161-207.

Lányí, B. (1987). Classical and rapid identification methods for medically important bacteria. Methods Microbiol 19, 1-67.

Leifson, E. (1963). Determination of carbohydrate metabolism of marine bacteria. J Bacteriol 85, 1183-1184.

Logan, N. A., Lebbe, L., Verhelst, A., Goris, J., Forsyth, G., RodríguezDíaz, M., Heyndrickx, M. \& De Vos, P. (2004). Bacillus shackletonii sp. nov., from volcanic soil on Candlemas Island, South Sandwich archipelago. Int J Syst Evol Microbiol 54, 373-376.

Marmur, J. (1961). A procedure for the isolation of deoxyribonucleic acid from microorganisms. J Mol Biol 3, 208-218.

Minnikin, D. E., Hutchinson, I. G., Caldicott, A. B. \& Goodfellow, M. (1980). Thin-layer chromatography of methanolysates of mycolic acid-containing bacteria. J Chromatogr A 188, 221-233.

Nam, S. W., Kim, W., Chun, J. \& Goodfellow, M. (2004). Tsukamurella pseudospumae sp. nov., a novel actinomycete isolated from activated sludge foam. Int J Syst Evol Microbiol 54, 1209-1212.

Nielsen, P., Rainey, F. A., Outtrup, H., Priest, F. G. \& Fritze, D. (1994). Comparative 16S rDNA sequence analysis of some alkaliphilic bacilli and the establishment of a sixth rRNA group within the genus Bacillus. FEMS Microbiol Lett 117, 61-66.

Pettersson, B., Lembke, F., Hammer, P., Stackebrandt, E. \& Priest, F. G. (1996). Bacillus sporothemodurans, a new species producing highly heat-resistant endospores. Int J Syst Bacteriol 46, 759-764.
Saitou, N. \& Nei, M. (1987). The neighbor-joining method: a new method for reconstructing phylogenetic trees. Mol Biol Evol 4, 406425.

Schleifer, K. H. (1985). Analysis of the chemical composition and primary structure of murein. Methods Microbiol 18, 123-156.

Shida, O., Takagi, H., Kadowaki, K. \& Komagata, K. (1996). Proposal for two new genera, Brevibacillus gen. nov. and Aneurinibacillus gen. nov. Int J Syst Bacteriol 46, 939-946.

Smibert, R. M. \& Krieg, N. R. (1994). Phenotypic characterization. In Methods for General and Molecular Bacteriology, pp. 607-654. Edited by P. Gerhardt, R. G. E. Murray, W. A. Wood \& N. R. Krieg. Washington, DC: American Society for Microbiology.

Stackebrandt, E. \& Goebel, B. M. (1994). Taxonomic note: a place for DNA-DNA reassociation and $16 \mathrm{~S}$ rRNA sequence analysis in the present species definition in bacteriology. Int J Syst Bacteriol 44, 846849.

Thompson, J. D., Gibson, T. J., Plewniak, F., Jeanmougin, F. \& Higgins, D. G. (1997). The CLUSTAL_X windows interface: flexible strategies for multiple sequence alignment aided by quality analysis tools. Nucleic Acids Res 25, 4876-4882.

Tindall, B. J. (1990a). A comparative study of the lipid composition of Halobacterium saccharovorum from various sources. Syst Appl Microbiol 13, 128-130.

Tindall, B. J. (1990b). Lipid composition of Halobacterium lacusprofundi. FEMS Microbiol Lett 66, 199-202.

Ventosa, A., Garcia, M. T., Kamekura, M., Onishi, H. \& RuizBerraquero, F. (1989). Bacillus halophilus sp. nov., a moderately halophilic Bacillus species. Syst Appl Microbiol 12, 162-166.

Wisotzkey, J. D., Jurtshuk, P., Jr, Fox, G. E., Deinhard, G. \& Poralla, K. (1992). Comparative sequence analysis on the 16S rRNA (rDNA) of Bacillus acidocaldarius, Bacillus acidoterrestris, and Bacillus cycloheptanicus and proposal for creation of a new genus, Alicyclobacillus gen. nov. Int J Syst Bacteriol 42, 263-269.

Yoon, J. H., Kim, I. G., Kang, K. H., Oh, T. K. \& Park, Y. H. (2004). Bacillus hwajinpoensis sp. nov. and an unnamed Bacillus genomospecies, novel members of Bacillus rRNA group 6 isolated from sea water of the East Sea and the Yellow Sea in Korea. Int J Syst Evol Microbiol 54, 803-808. 